\title{
56. GEOCHEMICAL HISTORY OF JAPAN TRENCH SEDIMENTS SAMPLED DURING LEG 56, DEEP SEA DRILLING PROJECT
}

\author{
Masato Nohara, Department of Marine Geology, Geological Survey of Japan, Tsukuba, Ibaraki, Japan
}

\section{INTRODUCTION}

A geological model of subduction postulated by Karig, Ingle, et al. (1975) and Karig and Sharman (1975) proposes that the sedimentary prism at the foot of the landward wall is being actively built as sediment is scraped off the subducting oceanic and plastered onto the base of the wedge, forming an accretionary wedge containing overthrust sedimentary layers or intense sedimentary folding. Because overlying layers must continually be uplifted and compressed to accommodate new matter at the base, the accreting wedge will provide a geochemical record of this process at or near the Japan Trench.

Several recent papers have discussed the metalliferous sediments on the active oceanic ridges. The geochemistry of such sediments is now reasonably well known: generally these deposits are considered products of volcanic processes (Boström and Peterson, 1969; Böstrom et al., 1969; Horowitz, 1970, 1974; Cronan et al., 1972; Cronan and Garrett, 1973). The geochemistry of subduction zone sediments, however, is less well known, and the need for studies of these sediments is particularly urgent if such sediments provide a record of the effects of subduction of oceanic plates under continental crust. Because the Japan Trench contains welldeveloped subduction zone deposits, Leg 56 sampling was of utmost importance to the discovery of how they originate.

\section{ANALYTICAL METHOD}

The sediment samples were dried at $<35^{\circ} \mathrm{C}$. Prior to chemical analysis, samples were ground $<200$ mesh with a Retisch mortar grinder. Chemical analyses were carried out on a Perkin-Elmer 503 atomic absorption spectrophotometer after a combined $\mathrm{HF}-\mathrm{HClO}_{4}-\mathrm{HCl}$ digestion that included double fuming with $\mathrm{HF}-\mathrm{HClO}_{4}$. All determinations were done in duplicate and precision and accuracy checked by JG-1 and JB-1, J. G. S. standards. In most cases, accuracy of concentrations of various elements in J. G. S. standard samples was in agreement within \pm 15 per cent for $\mathrm{Al}, \mathrm{Ti}$, and \pm 5 per cent for other elements.

\section{RESULTS AND DISCUSSION}

\section{Vertical Variations in Metal Enrichment}

The bulk chemical analyses of all the Leg 56 samples are presented on an untreated basis in Table 1 and Figure 1, because neither carbonate corrections nor normalizing to $\mathrm{Al}+\mathrm{Mn}+\mathrm{Ti}$, or $\mathrm{Al}_{2} \mathrm{O}_{3}$, as has been suggested by various other workers (Böstrom and Peterson,
1969; Böstrom et al., 1969; Piper, 1973), markedly alters the distribution patterns.

\section{Site 434 (Holes 434 and 434B) (Figure 1)}

This site is located on the lower inner trench wall at 5990 meters depth. The lithology of the sediments is very uniform diatomaceous ooze, mud, and mudstone with varying amounts of vitric ash. The color, presence of pyrite, and strong $\mathrm{H}_{2} \mathrm{~S}$ odor in the upper 250 meters indicate that the sediments were deposited under reducing conditions. They are composed almost entirely of pelagic ooze and hemipelagic mud.

As Table 1 and Figure 1 indicate, there are no remarkable variations in $\mathrm{Al}$ and $\mathrm{Ti}$ content at Site 434. Al content varies from 4.8 per cent to 8.6 per cent and averages 6.2 per cent, whereas $\mathrm{Ti}$ content ranges from 0.3 to 0.6 per cent and averages 0.4 per cent. Although we observed no systematic variations of $\mathrm{Al}$ and $\mathrm{Ti}$ in the core column, there are relatively large amounts of these elements in the vitric diatomaceous mudstone and tuffite below 300 meters.

Fe content varies from 1.6 to 8.8 per cent and averages 2.7 per cent. However, variations are generally small except at Sections 434-5-1 and 434-17-1, in which $\mathrm{Fe}$ values are two to three times greater. Fe enrichments do not necessarily occur at the reducing zone in which glauconite or pyrite is predominant. Therefore it appears likely that these minerals occur in minor quantities in this zone. Mn content is significantly variable, ranging from $330 \mathrm{ppm}$ to 0.48 per cent. Elevated Mn content (over $0.3 \%$ ) is observed at 102 meters $(0.48 \%), 344$ meters $(0.44 \%), 370$ meters $(0.33 \%)$ and 440 meters $(0.34 \%)$. These values are three- to four-fold the 0.1 per cent average at this site. High Mn content generally occurs in clay-rich sediments, which suggests that a process involving scavenging of metals from sea water, adsorption onto clays, and authigenic mineral formation is in operation.

Cu content in Hole 434 sediments shows small variation ( $58 \mathrm{ppm}-85 \mathrm{ppm}$ with an average of $70 \mathrm{ppm}$ ) relative to Hole 434B, where variation is marked ( $23 \mathrm{ppm}-$ $104 \mathrm{ppm}$ ). The relationship between $\mathrm{Fe}$ and $\mathrm{Cu}$ content in the reducing zone is so weak that sulfide minerals of both elements are not present at the same intervals within the zone. Zn distribution is fairly constant. Its highest value $(370 \mathrm{ppm})$ occurs in the section in which $\mathrm{Fe}$ and $\mathrm{Mn}$ concentrations are also high. Of other trace elements, $\mathrm{Ni}, \mathrm{Co}, \mathrm{Cr}$, and $\mathrm{Li}$ have similar distribution patterns throughout the cored sections at Site 434. The few higher $\mathrm{Sr}$ contents are due to the sporadic presence of carbonate through Holes 434 and 434B. The differences in chemical composition between Holes 434 and 
TABLE

Analytical Results of Sediment Samples from Deen Sea Drilling Project Leg 56

\begin{tabular}{|c|c|c|c|c|c|c|c|c|c|c|c|}
\hline $\begin{array}{c}\text { Sample } \\
\text { (Interval in } \mathrm{cm} \text { ) }\end{array}$ & $\begin{array}{c}\mathrm{Al} \\
(\%)\end{array}$ & $\begin{array}{c}\mathrm{Ti} \\
(\%)\end{array}$ & $\begin{array}{l}\mathrm{Fe} \\
(\%)\end{array}$ & $\begin{array}{c}\mathrm{Mn} \\
(\mathrm{ppm})\end{array}$ & $\begin{array}{c}\mathrm{Cu} \\
(\mathrm{ppm})\end{array}$ & $\begin{array}{c}\mathrm{Zn} \\
(\mathrm{ppm})\end{array}$ & $\begin{array}{c}\mathrm{Ni} \\
(\mathrm{ppm})\end{array}$ & $\begin{array}{c}\text { Co } \\
\text { (ppm) }\end{array}$ & $\begin{array}{c}\mathrm{Cr} \\
(\mathrm{ppm})\end{array}$ & $\begin{array}{c}\mathrm{Li} \\
(\mathrm{ppm})\end{array}$ & $\underset{(\mathrm{ppm})}{\mathrm{Sr}}$ \\
\hline \multicolumn{12}{|l|}{ Hole 434} \\
\hline 4, CC- $9-10$ & 6.70 & 0.53 & 2.47 & 1107 & 71 & 105 & 59 & 35 & 31 & 45 & 25 \\
\hline $5-1-42-43$ & 6.65 & 0.487 & 5.92 & 1138 & 83 & 83 & 54 & 25 & 49 & 36 & 39 \\
\hline $6, \mathrm{CC}-28-30$ & 5.93 & 0.38 & 2.64 & 485 & 78 & 88 & 40 & 10 & 39 & 34 & 21 \\
\hline $7-1-16-17$ & 5.27 & 0.38 & 2.07 & 432 & 58 & 102 & 42 & 23 & 45 & 33 & 1 \\
\hline $9-2-25-26$ & 6.84 & 0.47 & 2.00 & 393 & 75 & 75 & 37 & 28 & 52 & 43 & 2 \\
\hline $12-1-79-80$ & 5.41 & 0.41 & 2.18 & 4802 & 72 & 79 & 46 & 25 & 56 & 35 & 10 \\
\hline $15-1-12-13$ & 6.99 & 0.49 & 3.03 & 777 & 63 & 100 & 41 & 11 & 49 & 45 & 40 \\
\hline $20, \mathrm{CC}-34-35$ & 5.77 & 0.44 & 2.52 & 608 & 61 & 78 & 48 & 6 & 41 & 40 & 18 \\
\hline $23, \mathrm{CC}-12-15$ & 5.39 & 0.35 & 2.94 & 1133 & 58 & 196 & 44 & 9 & 52 & 37 & 75 \\
\hline $24, \mathrm{CC}-29-30$ & 5.78 & 0.45 & 2.27 & 458 & 73 & 208 & 56 & 30 & 67 & 39 & 2 \\
\hline $25-1-20-21$ & 5.84 & 0.39 & 2.93 & 991 & 69 & 139 & 56 & 35 & 52 & 35 & 31 \\
\hline $26, C C-22-24$ & 6.61 & 0.41 & 1.97 & 427 & 64 & 85 & 52 & 31 & 34 & 42 & 2 \\
\hline $27, \mathrm{CC}-23-24$ & 6.28 & 0.48 & 2.71 & 475 & 59 & 80 & 48 & 33 & 48 & 44 & 20 \\
\hline $28, \mathrm{CC}-17-19$ & 7.00 & 0.55 & 2.49 & 999 & 67 & 100 & 51 & 34 & 42 & 51 & 28 \\
\hline $29, \mathrm{CC}-25-26$ & 6.00 & 0.44 & 2.82 & 858 & 77 & 96 & 46 & 29 & 51 & 42 & 29 \\
\hline $30-1-100-103$ & 5.00 & 0.34 & 2.18 & 1537 & 85 & 79 & 41 & 16 & 42 & 37 & 13 \\
\hline $32-1-59-60$ & 6.72 & 0.40 & 4.76 & 1472 & 62 & 33 & 42 & 14 & 53 & 32 & 82 \\
\hline $33, \mathrm{CC}-12-13$ & 6.83 & 0.46 & 2.30 & 403 & 68 & 141 & 48 & 40 & 46 & 40 & 17 \\
\hline $33-2-100-102$ & 6.60 & 0.39 & 2.91 & 979 & 62 & 169 & 39 & 21 & 34 & 36 & 48 \\
\hline \multicolumn{12}{|l|}{ Hole 434B } \\
\hline $3, \mathrm{CC}-3-4$ & 6.11 & 0.38 & 1.85 & 485 & 67 & 76 & 44 & 27 & 38 & 36 & 5 \\
\hline $7-1-48-49$ & 6.23 & 0.38 & 2.35 & 4381 & 80 & 85 & 46 & 16 & 51 & 36 & 21 \\
\hline $8-2-142-148$ & 7.06 & 0.45 & 1.93 & 699 & 80 & 87 & 42 & 33 & 15 & 37 & 35 \\
\hline $9-3-84-85$ & 5.02 & 0.38 & 2.04 & 400 & 45 & 74 & 45 & 27 & 42 & 30 & 13 \\
\hline $10-6-86-87$ & 5.18 & 0.44 & 2.48 & 3257 & 83 & 83 & 56 & 24 & 59 & 38 & 29 \\
\hline $11-2-100-101$ & 5.62 & 0.36 & 2.64 & 1095 & 78 & 75 & 48 & 26 & 53 & 34 & 74 \\
\hline $15, \mathrm{CC}-0-2$ & 5.40 & 0.36 & 2.00 & 343 & 83 & 77 & 48 & 29 & 54 & 36 & 1 \\
\hline $16, \mathrm{CC}-0-2$ & 5.62 & 0.39 & 2.21 & 442 & 76 & 78 & 22 & 14 & 48 & 36 & 18 \\
\hline $17-1-148-150$ & 4.78 & 0.30 & 8.77 & 3449 & 58 & 365 & 59 & 16 & 64 & 26 & 150 \\
\hline $18-1-139-140$ & 7.16 & 0.44 & 2.47 & 435 & 66 & 89 & 54 & 32 & 53 & 47 & 4 \\
\hline $19-2-102-103$ & 8.55 & 0.55 & 2.72 & 1157 & 73 & 89 & 46 & 47 & 59 & 47 & 24 \\
\hline $20, \mathrm{CC}-3-4$ & 6.37 & 0.42 & 2.35 & 401 & 83 & 88 & 47 & 27 & 48 & 38 & 15 \\
\hline $24-2-56-57$ & 7.86 & 0.50 & 2.28 & 2023 & 104 & 94 & 55 & 35 & 51 & 47 & 1 \\
\hline $26, \mathrm{CC}-3-4$ & 6.38 & 0.36 & 1.59 & 663 & 44 & 77 & 25 & 21 & 25 & 26 & 19 \\
\hline 28, CC $-3-4$ & 5.86 & 0.35 & 1.59 & 738 & 23 & 61 & 21 & 16 & 19 & 19 & 28 \\
\hline $33, \mathrm{CC}-3-4$ & 7.80 & 0.48 & 2.26 & 1022 & 95 & 87 & 54 & 36 & 46 & 39 & 8 \\
\hline $34, \mathrm{CC}-2-3$ & 6.95 & 0.43 & 2.45 & 419 & 67 & 86 & 51 & 23 & 47 & 40 & 1 \\
\hline $36-1-47-48$ & 5.77 & 0.38 & 1.82 & 327 & 63 & 77 & 50 & 19 & 48 & 35 & 7 \\
\hline \multicolumn{12}{|l|}{ Hole 435} \\
\hline $2, \mathrm{CC}-8-10$ & 7.79 & 0.62 & 2.04 & 443 & 41 & 97 & 55 & 27 & 62 & 36 & 64 \\
\hline $5, \mathrm{CC}-14-15$ & 7.65 & 0.54 & 2.17 & 465 & 50 & 104 & 50 & 28 & 36 & 36 & 53 \\
\hline $6, \mathrm{CC}-17-18$ & 7.71 & 0.50 & 2.43 & 465 & 46 & 95 & 61 & 28 & 49 & 38 & 14 \\
\hline $8, \mathrm{CC}-0-2$ & 7.02 & 0.50 & 7.16 & 1318 & 54 & 152 & 61 & 27 & 99 & 31 & 50 \\
\hline $9, \mathrm{CC}-11-13$ & 2.91 & 0.28 & 1.29 & 344 & 43 & 79 & 33 & 13 & 29 & 21 & 28 \\
\hline $10-1-61-62$ & 8.05 & 0.54 & 1.73 & 402 & 52 & 91 & 56 & 23 & 48 & 47 & 53 \\
\hline $10, \mathrm{CC}-11-12$ & 5.51 & 0.44 & 2.13 & 344 & 49 & 88 & 43 & 21 & 38 & 30 & 59 \\
\hline $11-1-83-84$ & 6.45 & 0.38 & 1.75 & 382 & 80 & 92 & 20 & 14 & 37 & 35 & 63 \\
\hline $12-1-80-81$ & 5.89 & 0.40 & 1.89 & 356 & 45 & 91 & 36 & 15 & 44 & 37 & 174 \\
\hline $13, \mathrm{CC}-2-3$ & 4.96 & 0.29 & 1.61 & 328 & 34 & 79 & 38 & 11 & 33 & 26 & 183 \\
\hline $14, \mathrm{CC}-2-3$ & 3.45 & 0.30 & 1.50 & 251 & 41 & 72 & 39 & 12 & 37 & 29 & 63 \\
\hline $15, \mathrm{CC}-12-13$ & 3.72 & 0.23 & 1.49 & 222 & 41 & 82 & 42 & 15 & 33 & 31 & 39 \\
\hline $16, \mathrm{CC}-1-2$ & 2.97 & 0.23 & 1.26 & 265 & 36 & 73 & 35 & 35 & 31 & 23 & 14 \\
\hline \multicolumn{12}{|l|}{ Hole 435A } \\
\hline $1, \mathrm{CC}-1-2$ & 7.24 & 0.56 & 2.16 & 477 & 32 & 93 & 51 & 40 & 56 & 49 & 44 \\
\hline $2-1-104-106$ & 3.16 & 0.30 & 2.12 & 361 & 35 & 86 & 34 & 23 & 41 & 28 & 46 \\
\hline $4, \mathrm{CC}-7-8$ & 4.16 & 0.31 & 1.27 & 202 & 38 & 76 & 37 & 20 & 43 & 33 & 35 \\
\hline $6, \mathrm{CC}$ & 3.96 & 0.27 & 1.17 & 192 & 44 & 81 & 38 & 19 & 46 & 28 & 37 \\
\hline $7, \mathrm{CC}-21-23$ & 3.03 & 0.26 & 1.29 & 205 & 47 & 77 & 32 & 17 & 42 & 25 & 26 \\
\hline $9-2-141-142$ & 3.54 & 0.28 & 1.54 & 181 & 38 & 80 & 33 & 16 & 48 & 30 & 33 \\
\hline $10-1-106-107$ & 3.69 & 0.28 & 1.39 & 246 & 48 & 88 & 30 & 14 & 42 & 26 & 20 \\
\hline $11-2-95-96$ & 4.38 & 0.33 & 1.59 & 430 & 51 & 104 & 35 & 18 & 54 & 32 & 111 \\
\hline $11, \mathrm{CC}-25-26$ & 5.37 & 0.38 & 1.75 & 320 & 60 & 115 & 43 & 20 & 61 & 42 & 20 \\
\hline
\end{tabular}


TABLE 1 - Continued

\begin{tabular}{|c|c|c|c|c|c|c|c|c|c|c|c|}
\hline $\begin{array}{c}\text { Sample } \\
\text { (Interval in } \mathrm{cm} \text { ) }\end{array}$ & $\begin{array}{r}\mathrm{Al} \\
(\%)\end{array}$ & $\begin{array}{c}\mathrm{Ti} \\
(\%)\end{array}$ & $\begin{array}{l}\mathrm{Fe} \\
(\%)\end{array}$ & $\underset{(\mathrm{ppm})}{\mathrm{Mn}}$ & $\begin{array}{c}\mathrm{Cu} \\
(\mathrm{ppm})\end{array}$ & $\begin{array}{c}\mathrm{Zn} \\
(\mathrm{ppm})\end{array}$ & $\begin{array}{c}\mathrm{Ni} \\
(\mathrm{ppm})\end{array}$ & $\begin{array}{c}\mathrm{Co} \\
(\mathrm{ppm})\end{array}$ & $\begin{array}{c}\mathrm{Cr} \\
(\mathrm{ppm})\end{array}$ & $\begin{array}{c}\mathrm{Li} \\
(\mathrm{ppm})\end{array}$ & $\begin{array}{c}\mathrm{Sr} \\
(\mathrm{ppm})\end{array}$ \\
\hline \multicolumn{12}{|l|}{ Hole 436} \\
\hline $2-3-100-101$ & 6.79 & 0.45 & 2.04 & 481 & 72 & 102 & 46 & 31 & 38 & 34 & 29 \\
\hline $3-5-145-146$ & 7.32 & 0.53 & 2.29 & 474 & 82 & 53 & 76 & 45 & 50 & 44 & 29 \\
\hline $4-5-120-121$ & 7.97 & 0.57 & 2.59 & 418 & 80 & 128 & 73 & 46 & 56 & 51 & 33 \\
\hline $5-4-140-141$ & 8.15 & 0.54 & 2.33 & 448 & 91 & 124 & 63 & 36 & 36 & 49 & 24 \\
\hline $6-5-57-58$ & 8.07 & 0.43 & 1.87 & 530 & 46 & 96 & 51 & 37 & 28 & 34 & 31 \\
\hline $8-5-2-3$ & 7.75 & 0.49 & 2.38 & 482 & 80 & 104 & 62 & 35 & 35 & 38 & 23 \\
\hline $9-5-10-11$ & 8.82 & 0.49 & 2.11 & 408 & 95 & 109 & 56 & 38 & 29 & 44 & 17 \\
\hline $10-2-29-30$ & 6.76 & 0.42 & 3.02 & 483 & 101 & 131 & 87 & 42 & 28 & 39 & 11 \\
\hline $11-7-19-20$ & 7.47 & 0.51 & 2.65 & 383 & 131 & 129 & 62 & 39 & 36 & 46 & 26 \\
\hline $12-6-23-24$ & 7.05 & 0.50 & 2.47 & 470 & 95 & 117 & 49 & 39 & 37 & 46 & 32 \\
\hline $13-5-90-91$ & 7.59 & 0.52 & 2.06 & 486 & 83 & 119 & 52 & 38 & 46 & 44 & 30 \\
\hline $14-4-60-61$ & 7.02 & 0.35 & 1.82 & 461 & 60 & 96 & 43 & 28 & 27 & 27 & 47 \\
\hline $15-7-44-45$ & 6.21 & 0.39 & 2.50 & 430 & 90 & 115 & 52 & 30 & 38 & 31 & 44 \\
\hline $16-7-40-41$ & 7.15 & 0.48 & 2.10 & 358 & 105 & 124 & 47 & 29 & 46 & 42 & 38 \\
\hline $17, \mathrm{CC}-8-10$ & 7.11 & 0.26 & 2.03 & 534 & 118 & 103 & 49 & 26 & 20 & 39 & 27 \\
\hline $18-2-69-70$ & 6.88 & 0.38 & 1.77 & 337 & 42 & 94 & 39 & 27 & 27 & 38 & 43 \\
\hline $19-4-148-149$ & 6.45 & 0.46 & 2.63 & 361 & 53 & 104 & 41 & 26 & 37 & 48 & 35 \\
\hline $20-2-40-41$ & 7.80 & 0.49 & 2.01 & 412 & 90 & 108 & 51 & 36 & 26 & 44 & 22 \\
\hline $21-1-40-41$ & 8.10 & 0.49 & 2.31 & 422 & 147 & 122 & 58 & 36 & 40 & 56 & 15 \\
\hline $23-3-50-51$ & 7.07 & 0.48 & 2.28 & 339 & 101 & 124 & 47 & 30 & 39 & 51 & 11 \\
\hline $24-2-60-61$ & 7.67 & 0.45 & 2.59 & 693 & 122 & 107 & 43 & 35 & 31 & 47 & 7 \\
\hline $25-1-66-67$ & 7.05 & 0.44 & 2.15 & 392 & 57 & 92 & 51 & 34 & 35 & 44 & 10 \\
\hline $26, \mathrm{CC}-15-16$ & 6.66 & 0.41 & 2.16 & 324 & 56 & 99 & 46 & 30 & 47 & 41 & 10 \\
\hline $28-1-119-120$ & 7.56 & 0.48 & 2.20 & 339 & 49 & 101 & 41 & 36 & 42 & 46 & 2 \\
\hline 29. CC $-19-20$ & 7.18 & 0.18 & 1.17 & 468 & 33 & 47 & 47 & 30 & 10 & 16 & 1 \\
\hline $30, \mathrm{CC}-15-16$ & 7.40 & 0.40 & 2.55 & 2149 & 14 & 98 & 29 & 39 & 35 & 38 & 1 \\
\hline $31-5-13-14$ & 7.01 & 0.34 & 2.89 & 1395 & 90 & 96 & 54 & 38 & 33 & 42 & 13 \\
\hline $32-2-137-138$ & 8.58 & 0.47 & 3.28 & 5993 & 32 & 109 & 67 & 42 & 30 & 46 & 10 \\
\hline $33-6-55-57$ & 8.53 & 0.46 & 1.93 & 4481 & 55 & 95 & 69 & 47 & 22 & 40 & 6 \\
\hline $34-4-70-71$ & 8.08 & 0.45 & 3.06 & 5075 & 55 & 99 & 72 & 49 & 29 & 43 & 15 \\
\hline $35-6-66-67$ & 9.03 & 0.52 & 3.33 & 3345 & 15 & 103 & 72 & 46 & 35 & 47 & 1 \\
\hline $36-4-73-74$ & 8.72 & 0.49 & 2.57 & 1367 & 100 & 96 & 81 & 56 & 24 & 41 & 6 \\
\hline $37-6-93-94$ & 9.15 & 0.52 & 2.42 & 2440 & 171 & 110 & 102 & 65 & 35 & 49 & 1 \\
\hline $38-7-44-45$ & 8.41 & 0.62 & 4.28 & 11919 & 268 & 136 & 190 & 115 & 39 & 67 & 2 \\
\hline $39-5-117-118$ & 7.49 & 0.47 & 2.73 & 3415 & 90 & 98 & 69 & 53 & 38 & 46 & 3 \\
\hline $40-5-80-81$ & 1.55 & 0.49 & 4.27 & 16279 & 209 & 163 & 369 & 155 & 46 & 59 & 5 \\
\hline
\end{tabular}

434B seem due to the discontinuity from diatomaceous ooze or diatomaceous mudstone to vitric diatomaceous mudstone or tuffite.

\section{Site 435 (Holes 435 and 435A) (Figure 2)}

The sediments cored at Site 435 represent hemipelagic deposits draped on the upper slope of the landward wall of the Japan Trench. The sediments are clay with a small percentage of silt and sand. Period of deposit is as follows: Pleistocene, 0 to 84 meters; upper Pliocene, 84 to 110 meters; and lower Pliocene, 110 to 245 meters.

Of the major elements, $\mathrm{Al}$ and $\mathrm{Ti}$ are plentiful in the upper sections and gradually decrease with depth to about 200 meters. Below 200 meters they tend to increase. $\mathrm{Fe}$ and $\mathrm{Mn}$ content shows similar distribution patterns. The highest values of both elements - Fe, 7.2 per cent; Mn, 0.13 per cent - occur in Sample 435-8, $\mathrm{CC}(68 \mathrm{~m})$, in which $\mathrm{Cu}, \mathrm{Zn}$, and $\mathrm{Cr}$ are also most abundant. $\mathrm{Ni}, \mathrm{Co}$, and $\mathrm{Li}$ are uniformly distributed throughout the different time. On the other hand, $\mathrm{Sr}$ is remarkably variable, ranging from $14 \mathrm{ppm}$ to $183 \mathrm{ppm}$ and averaging $65 \mathrm{ppm}$. Elevated $\mathrm{Sr}$ content occurs in Samples 435-12-1 and 435-13, CC (100-110 m), corresponding to the late Pliocene. Generally, $\mathrm{Al}, \mathrm{Ti}$, and Fe concentrations in Site 435 samples are either somewhat less than or similar to those in Site 434 sediment, whereas Mn and $\mathrm{Cu}$ are remarkably depleted at Site 435 . Other trace elements in Site 435 sediments display the same magnitude of concentration as those from Site 434, except for $\mathrm{Sr}$, which is twice as plentiful.

\section{Site 436 (Figure 3)}

Site 436 is located at the crest of the outer swell of the Japan Trench in a water depth of 5205 meters. The sediments recovered are very similar to those sampled at DSDP Sites 194 and 195, south of Site 436. Most of the sections consist of Neogene sediments that are mainly vitric diatomaceous mud and, below 250 meters, mudstone. Their ages range from Quaternary at the top to Miocene at about 360 meters. Ash layers 1 to $10 \mathrm{~cm}$ thick are common throughout the Quaternary and Pliocene sections and especially abundant in the Pliocene.

At this site, $\mathrm{Al}$ and $\mathrm{Ti}$ content shows irregular periodic variation irrespective of geological age. Overall, $\mathrm{Al}$ and $\mathrm{Ti}$ content is high $(\mathrm{Al}, 0.71 \% ; \mathrm{Ti}, 0.45 \%)$ relative to Sites 434 and 435 . Although $\mathrm{Fe}$ and $\mathrm{Cu}$ are also irregularly distributed, their values tend to increase toward the bottom sections, which are pelagic clay. $\mathrm{Mn}, \mathrm{Ni}$, and $\mathrm{Co}$ are fairly constant down to 270 meters (Pleistocene to late Miocene). Their high values occur in yellowish- 


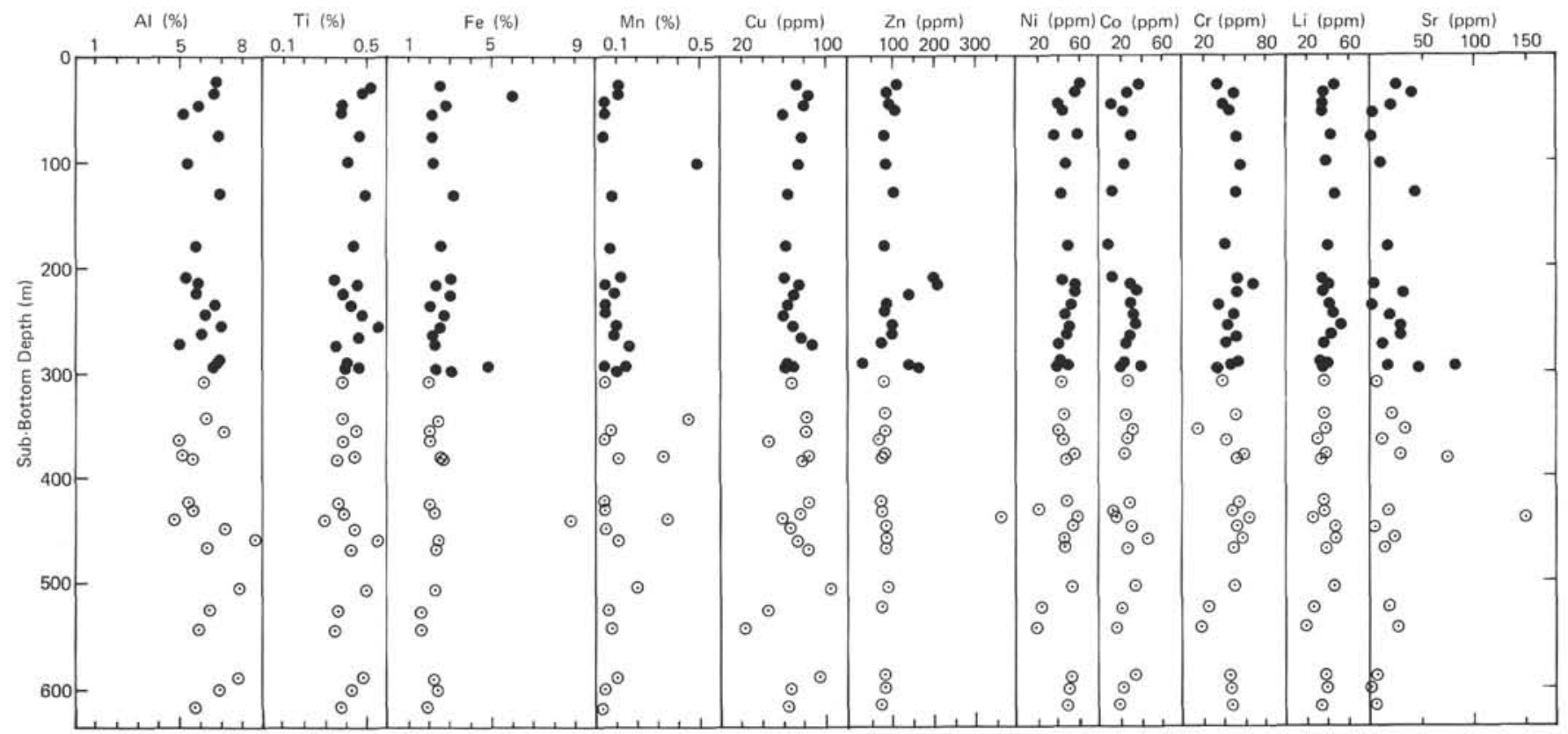

Figure 1. Sediment composition of Site 434, uncorrected for carbonate and salt, versus depth from sediment surface. (Solid circle represents Hole 434 sediments; circle with center dot represents Hole 434B sediments.)

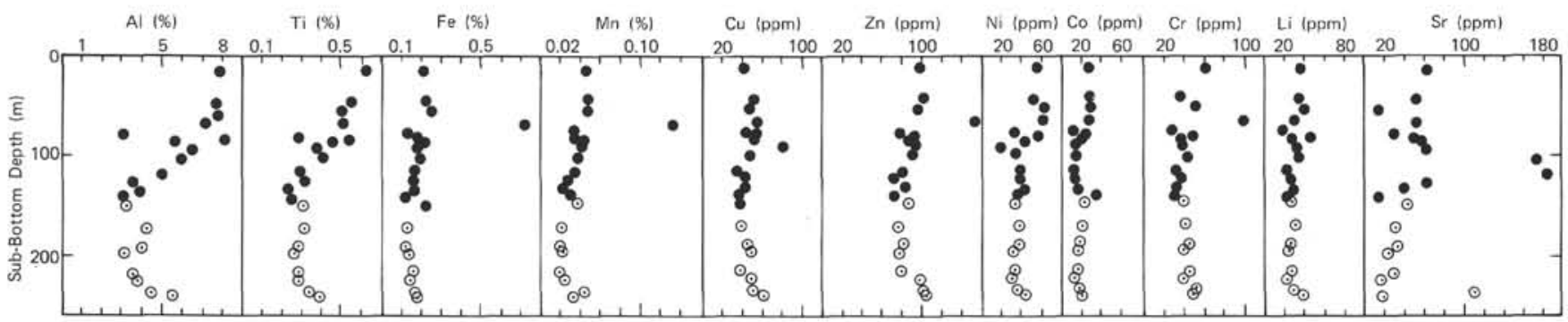

Figure 2. Sediment composition of Site 435, uncorrected for carbonate and salt, versus depth from sediment surface. (Solid circle represents Hole 435 sediments; circle with center dot represents Hole $435 \mathrm{~A}$ sediments.)

brown Cretaceous-middle Miocene sediment, which is composed of very fine clay with abundant amorphous iron-manganese hydroxides. This sediment was apparently deposited in a pelagic environment of low biological productivity well below carbonate compensation depth. $\mathrm{Cr}$ and $\mathrm{Li}$ are generally uniform through all the sections, although small variations occur. $\mathrm{Sr}$ is abundant between 100 and 180 meters; below 200 meters it is very scarce.

\section{Sedimentation Rates}

The data in Table 2 have been calculated using the compositional data in Table 1, shipboard bulk density measurements, and paleontological age. However, there are problems with these calculated sedimentation rates. Uncertainties in dating and in physical properties may produce errors on the order of 10 to 30 per cent. More serious are the errors that may have been physiographically induced: for example, such topographical phenomena as slumping, folding, turbidity, or gentle winnowing of matter may distort sedimentation rates.

Sedimentation rates at Site 434 range from $26 \mathrm{~mm} /$ $1000 \mathrm{yr}$ to $49 \mathrm{~mm} / 1000 \mathrm{yr}$ through the Pleistocene-late
Pliocene. These high rates indicate a hemipelagic to shallow rather than pelagic depositional environment. Sedimentation rates at Site 435 are significantly higher in later deposits than in earlier ones and indicate that the sediments from this site originated in the continental margin area. Sedimentation rates at Site 436 show that the sedimentary environment gradually changed from pelagic to hemipelagic, implying that the ocean crust at Site 436 has been moving landward across the Pacific mid-latitudes from the Early Cretaceous to the present, as suggested by Lancelot and Larson (1975).

\section{Metal Accumulation Rates}

The data in Table 3 were calculated using the data in Table 1 and sedimentation rates in Table 2 .

Most studies of marine sediments have concluded that $\mathrm{Al}, \mathrm{Ti}$, and nonbiogenous $\mathrm{Si}$ concentrations are controlled primarily by accumulation of detrital phases, whereas $\mathrm{Fe}$ and $\mathrm{Mn}$ principally reflect the abundance of authigenic constituents. This concept is undoubtedly true for many regions in the ocean.

The accumulation rates for metal constituents tend to be higher in near-surface than in near-basement sedi- 
ments. Accumulation rates of $\mathrm{Fe}, \mathrm{Mn}, \mathrm{Cu}$, and $\mathrm{Ni}$, which represent authigenic fractions, are high in Pleistocene sediments, especially at Site 435 . Similarly, $\mathrm{Al}$ and $\mathrm{Ti}$ accumulation rates reach a maximum in the Pleistocene. This fact may be due to breakdown of $\mathrm{Fe}-\mathrm{Mn}$ oxides and upward migration of $\mathrm{Mn}$ and its associated metals. The description of the younger sediments from Sites 434 and 435 includes the fact that very strong $\mathrm{H}_{2} \mathrm{~S}$ odor accompanied all cores down to 250 meters at Site 434 and that pyritized diatomaceous sediments extended from the Pleistocene to the early Pliocene at Site 435, indicating reducing conditions. Although under strong to mildly reducing conditions, the behavior of $\mathrm{Fe}, \mathrm{Mn}$, and $\mathrm{Cu}$ as well as of $\mathrm{Zn}$ and $\mathrm{Ni}$ is variable, the general trend for all these elements is toward upward mobility (Duchart et al., 1973). An alternative hypothesis is that the high accumulation rates of these elements in the younger sediments might be the result of island arc volcanic activity during the late Neogene to Recent on the nearby Japanese islands.

At Site 436, Al, $\mathrm{Ti}, \mathrm{Co}, \mathrm{Cr}, \mathrm{Li}$, and $\mathrm{Sr}$ accumulation rates are higher in the early Pliocene-Pleistocene than in the Middle-late Miocene. Much greater amounts of $\mathrm{Cu}$, $\mathrm{Zn}$, and $\mathrm{Ni}$ are accumulated in the upper sediments than in the lower. On the other hand, Mn accumulation rate is higher in the near-bottom. This finding is consistent with the fact that between the late Miocene and the early Pliocene the lithology of sediments gradually changed from pelagic clay with abundant manganese oxides to vitric diatomaceous mud. It is possible that the high $\mathrm{Fe}$ accumulation rate in the upper core sections is ascribable to volcanic materials which, as indicated by vitric ash layers and disseminated glass, were first deposited during the early Pliocene.

\section{CONCLUSIONS}

Bulk chemical analyses of sediments collected from the Japan Trench show that the metal content is generally not as high as for present-day active ridge and normal pelagic sediments, with the exception of the high $\mathrm{Fe}$ and Mn content at Site 434. Near-basement sediments at Site 436, however, do contain the elevated amounts of Fe, $\mathrm{Mn}, \mathrm{Cu}, \mathrm{Co}$, and $\mathrm{Ni}$ as same as normal Pacific pelagic sediments. Vertical abundance of elements is variable but small throughout time, indicating that the nature of detrital input and authigenic element deposition has been relatively constant since the middle-early Miocene. Chemical characteristics of the inner trench sediments (Sites 434 and 435) indicate that they are of island arc origin. It seems possible, therefore, that the materials constituting the accretionary wedge also originate in island arc rather than oceanic sediments. Bulk geochemistry of sediments from Sites 434 and 435 suggests that postdepositional migration of $\mathrm{Mn}, \mathrm{Ni}, \mathrm{Cu}$, and $\mathrm{Zn}$ may have occurred.

Sedimentation rates are as follows: $2.5-5 \mathrm{~cm} / 1000 \mathrm{yr}$ from the early Miocene to the late Pliocene at Site 434; $0.7-26 \mathrm{~cm} / 1000 \mathrm{yr}$ from the early Pliocene to the late Pleistocene at Site $435 ; 1.2-5 \mathrm{~cm} / 1000 \mathrm{yr}$ at Site 436 . These values are markedly greater than those of typical

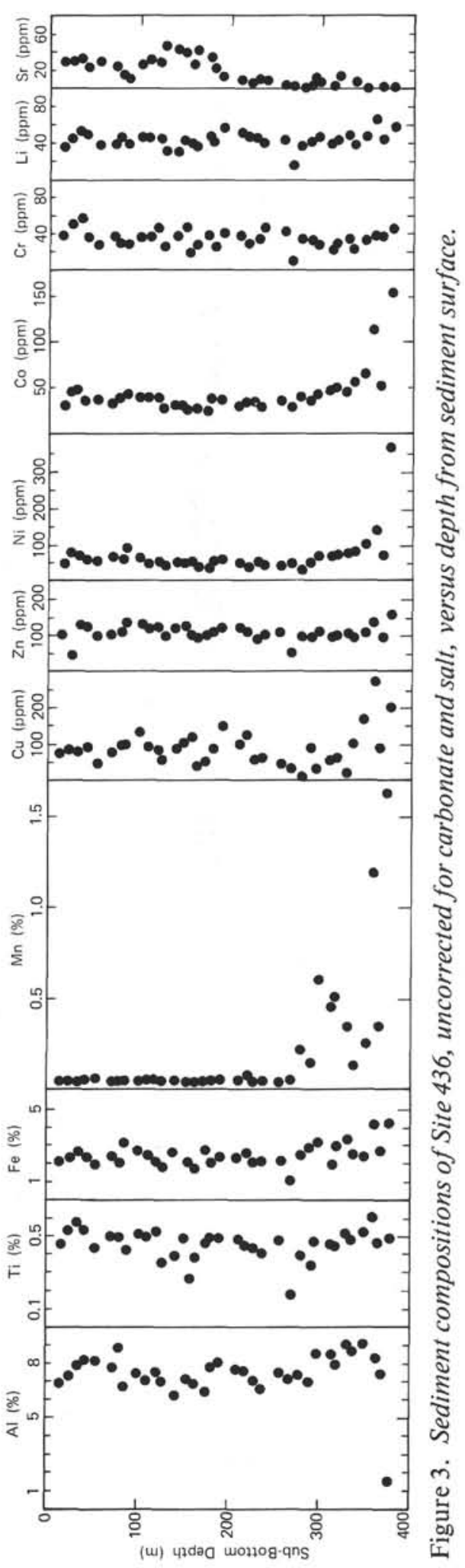


TABLE 2

Sample Distribution, Physical Properties, Geochronology, and Accumulation Rates for Sediments from Deep Sea Drilling Project Leg 56

\begin{tabular}{|c|c|c|c|c|c|c|c|c|c|}
\hline Hole & Core/Section & $\begin{array}{l}\text { Density } \\
(\mathrm{g} / \mathrm{cc})\end{array}$ & $\begin{array}{l}\text { Sub-Bottom } \\
\text { Depth } \\
\text { (m) }\end{array}$ & $\begin{array}{l}\text { Thickness } \\
\text { (m) }\end{array}$ & $\begin{array}{l}\text { Age } \\
\text { (m.y.) }\end{array}$ & \multicolumn{2}{|c|}{$\begin{array}{c}\text { Sedimentation } \\
\text { Rate } \\
(\mathrm{mm} / 1000 \mathrm{yr})\end{array}$} & \multicolumn{2}{|c|}{$\begin{array}{c}\text { Accumulation } \\
\text { Rate } \\
\left(\mathrm{mg} / \mathrm{cm}^{2} / 1000 \mathrm{yr}\right)\end{array}$} \\
\hline 434 & $4, \mathrm{CC}$ to $5-1$ & 1.40 & $6.5-45$ & 38.5 & $3.3-1.8$ & 25.7 & & 3598 & \\
\hline 434 & $7-1$ to $12-1$ & 1.44 & $54-110$ & 56.0 & $5.0-3.3$ & 32.9 & & 4738 & \\
\hline 434 & $15-1$ & 1.59 & $120.5-130$ & 9.5 & $5.0-3.3$ & 5.6 & 491 & 894 & 7770 \\
\hline 434 & $20, \mathrm{CC}$ to $29, \mathrm{CC}$ & 1.50 & $187-263$ & 76.0 & $5.0-3.3$ & 44.7 & 49.1 & 6700 & 17170 \\
\hline $434 \mathrm{~B}$ & $32-1$ to $19-2$ & 1.66 & $272.5-465$ & 192.5 & $5.0-3.3$ & 113.0 & & 18,758 & \\
\hline 434 & $20, \mathrm{CC}$ to $34, \mathrm{CC}$ & 1.82 & $465-609$ & 144.0 & $10.6-5.0$ & 25.7 & & 4550 & \\
\hline 435 & $2, \mathrm{CC}$ & 1.43 & $0-36.5$ & 36.5 & $0.15-0.01$ & 261.0 & & 37,323 & \\
\hline 435 & $5, \mathrm{CC}$ to $8, \mathrm{CC}$ & 1.50 & $36.5-74.5$ & 38.0 & $0.5-0.15$ & 109.0 & & 16,350 & \\
\hline 435 & $9, \mathrm{CC}$ & 1.45 & $74.5-84$ & 9.5 & $1.8-0.5$ & 7.3 & & 1059 & \\
\hline 435 & $10-1$ to $12, \mathrm{CC}$ & 1.34 & $84-112.5$ & 28.5 & $3.3-1.8$ & 19.0 & & 2546 & \\
\hline $435 \mathrm{~A}$ & $14, \mathrm{CC}$ to $11, \mathrm{CC}$ & 1.35 & $122-244.5$ & 122.5 & $5.0-3.3$ & 72.1 & & 9734 & \\
\hline 436 & $2-3$ to $9-5$ & 1.41 & $0-84$ & 84.0 & $1.8-0.01$ & 46.9 & & 6613 & \\
\hline 436 & $11-7$ to $14-4$ & 1.38 & $93-131.5$ & 38.5 & $3.3-1.8$ & 25.7 & & 3547 & \\
\hline 436 & $18-2$ to $26, \mathrm{CC}$ & 1.34 & $160-245$ & 85.0 & $5.0-3.3$ & 50.0 & & 6700 & \\
\hline 436 & $28-1$ to $33-6$ & 1.45 & $245-312$ & 67.0 & $10.6-5.0$ & 12.0 & & 1740 & \\
\hline 436 & $34-4$ to $38-7$ & 1.55 & $312-360$ & 48.0 & $15.0-10.6$ & 10.9 & & 1690 & \\
\hline
\end{tabular}

TABLE 3

Accumulation Rates for Constituents in Sediments from Deep Sea Drilling Project Leg 56

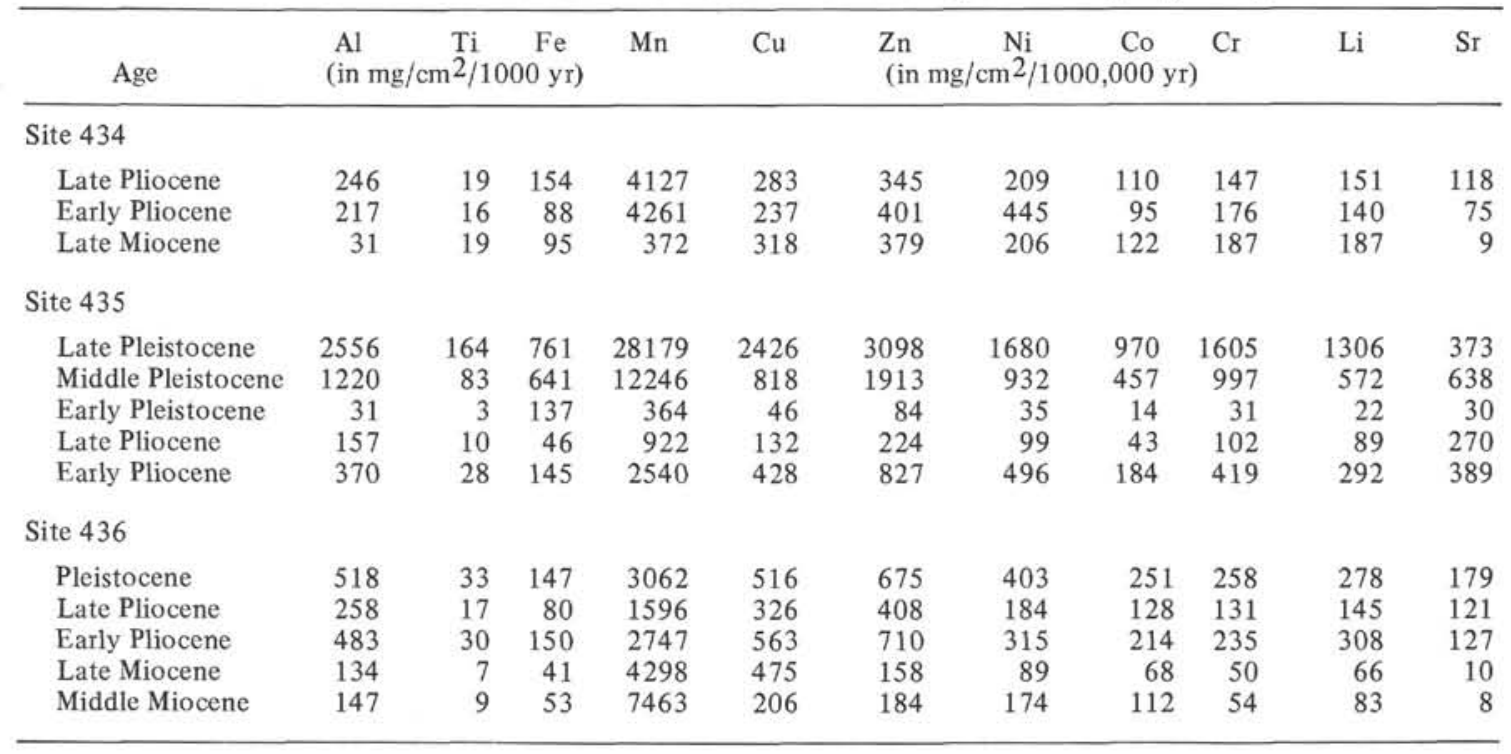

sedimentation rates for deep sea pelagic sediments, indicating the truly hemipelagic nature of these sediments.

Metal accumulation rates from the early Pliocene to the late Pleistocene are equally high. Of authigenic fractions, $\mathrm{Fe}$ and $\mathrm{Mn}$ have considerably high accumulation rates in the near-surface sediments, where detritus constituents such as $\mathrm{Al}$ and $\mathrm{Ti}$ are also high. This finding indicates that $\mathrm{Fe}$ and $\mathrm{Mn}$ content is significantly influenced by island arc volcanic activity during the late Neogene to Recent on the nearby Japanese islands.

\section{ACKNOWLEDGMENTS}

I would like to thank Drs. Hakuyu Okada and Takashi Fujii for reviewing the manuscript and Miss $\mathrm{C}$. Orihara for sample preparation and for typing this chapter.

\section{REFERENCES}

Boström, K., and Peterson, M., 1969. Origin of aluminumpoor sediments in areas of high heat flow on the East Pacific Rise. Mar. Geol., 7, 427-447.

Boström, K., Peterson, M., Joensuu, O., and Fisher, D., 1969. J. Geophys. Res., 74, 3261-3270.

Cronan, D., and Garrett, D., 1973. The distribution of elements in metalliferous Pacific sediments collected during the D.S.D.P. Nature Phys. Sci., 242, 88-89.

Cronan, D., van Andel, Tj., Heath, G., Dinkelman, M., Bennett, R., Bukry, D., Charleston, S., Knapps, A., Rodolfo, K., and Yeats, R., 1972. Iron-rich basal sediments from the eastern equatorial Pacific: Leg XVI, D.S.D.P. Science, 175, 61-63. 
Duchart, P., Calvert, S., and Price, N., 1973. Distribution of trace metals in the pore waters of shallow marine sediments. Limnol. Oceanogr., 18, 605-610.

Horowitz, A., 1970. The distribution of $\mathrm{Pb}, \mathrm{Ag}, \mathrm{Sn}, \mathrm{Ti}$, and $\mathrm{Zn}$ in sediments on active oceanic ridges. Mar. Geol., 9, 241-259.

1974. The geochemistry of sediments from the northern Reykjanes Ridge and the Iceland-Faroes Ridge. Mar. Geol., 17, 103-122.
Karig, D. E., Ingle, J. C., Jr., et al., 1975. Init. Repts. DSDP, 31: Washington (U.S. Govt. Printing Office).

Karig, D. E., and Sharman, G. F., 1975. Subduction and accretion in trenches. Geol. Soc. Am. Bull., 86, 377-389.

Lancelot, Y., and Larson, R. L., 1975. Sedimentary and tectonic evolution of the Northwestern Pacific. In Larson, R. L., Moberly, R., et al., 1975. Init. Repts. DSDP, 32: Washington (U.S. Govt. Printing Office), 925-939.

Piper, D., 1973. Origin of metalliferous sediments from the East Pacific Rise. Earth Planet. Sci. Lett., 19, 75-82. 